\title{
Print Culture and Visual Interpretation in Eighteenth-Century German Editions of Thomson's The Seasons
}

\author{
SANDRO JUNG
}

The reception and translation of eighteenth-century British poetry in the German-speaking world has been insufficiently charted. While there are detailed studies of Alexander Pope's influence on and presence in the eighteenth-century poetic landscape and the book trade of German-speaking countries, ${ }^{\mathrm{I}}$ the adaptation of Pope in print-cultural terms, the uses of paratextual material to supplement and explicate the text, as well as the illustrative paratexts frequently accompanying his editions, have not yet been explored. ${ }^{2}$ Pope's canonic status has certainly ensured that scholars have traced the reception of his works, his self-fashioning, and the adaptation and reworking of his works in satiric and philosophical writings, but lyric and descriptive poets of the period, including William Collins and Thomas Gray, have largely and unduly been neglected. James Thomson (I700-I748), one of the most important poets of his day, is a case in point. His intertextual presence was examined long ago by Knut Gjerset who, in his doctoral dissertation Der Einfluss James Thomsons Fahreszeiten auf die deutsche Literatur des I8. Fahrhunderts (1898), ${ }^{3}$ introduced a range of poetic works that demonstrated and exemplified poets' hypotextual transformation-in terms of literal translation or imitation-of Thomson's long poem. Gjerset offered a descriptive source studies account and charted authors' reading and textual/ideational transpositions of Thomson's poem. His approach is anchored in an exploration of the literary textuality of The Seasons and does not take into account the cultural ramifications of the poem's widespread popularity and currency throughout the second half of the eighteenth and first half of the nineteenth centuries. Yet, in view of the wider cultural significance of the text, the exclusive literary approach used by Gjerset and early twentieth-century critics 
is limiting; its combination with an exploration of the print cultural contexts, a consideration of the fashioning and rewriting of Thomson's text by means of critical paratexts, and the embedding of these paratexts - especially the different illustrations accompanying editions of The Seasons - into a discussion informed by British models of illustration, promises to yield important insights into the ways Thomson's work was understood and consumed by German-language readers. This more complex approach reads the text as part of a cultural and economic narrative that, in Britain, was reflected by the ever new editions that were produced from I 730 until the end of the nineteenth century. It facilitates an assessment of German illustrative paratexts in terms of an industry of cultural spin-offs such as, among many others, paintings, porcelain, fans, and furniture designs, as well as a diverse range of cultural commodities, that featured visual interpretations of signature scenes or episodes from the poem. ${ }^{4}$ Thomson's The Seasons, especially after its publication in European countries (including France, Italy, Spain, Sweden, and the Netherlands) in both translation and its original language, was one of the best-selling works of the time; however, its painterly commodification and the negotiation of the visual models produced by eighteenth-century British booksellers not only offer information on particular ways in which the poem was read but also in which ways booksellers formulated interpretations that were distinctly different from those produced in Britain and elsewhere to 'naturalize' the poem and appropriate it - in visual and linguistic terms - to a Germanspeaking readership. In other words, booksellers sought to distinguish their editions not only from those produced in the German-speaking, Anglophile intellectual communities but also from earlier British editions (some of which would have competed with continental editions on the German market). As a result, they constructed a cultural archive that could enhance cultural progress in Germany, where the appreciation of British literature, particularly towards the end of the eighteenth century, became an inherent indicator of polite education.

Published in I 730 by the London-based Andrew Millar, Thomson's The Seasons was issued in illustrated editions from the start. Millar had commissioned the Palladian architect and landscape designer, William Kent (c. I685-I748), to produce four mythopoeic narrative tableau plates that would accompany the poem until the lapse of Millar's copyright in 1765.5 Millar's ability to control the production, marketing, and paratextual make-up of editions of the poem for almost thirtyfive years resulted in his exclusive use of Kent's allegorical until the 
late 1760 s. From $\mathrm{i} 766$, however, novel visual interpretations illustrating selected episodes from The Seasons were produced, the first of which was William Woollett's copper-engraved furniture print (after Richard Wilson's now lost oil painting $A$ Summer Storm), a print also marketed on the continent and re-engraved in France. ${ }^{6}$ Editions not issued by Millar or his successors provided alternative illustrative narratives, at the same time also including a range of different critical essays on the poem by John Aikin, John More, and Robert Heron, short biographies of Thomson, glossaries, dedications, and subscription or advertising information. As German-speaking countries were not subject to British copyright legislation, their bookseller-publishers innovatively equipped their editions in ways that were novel by including specially commissioned designs and other interpretative, paratextual materials. By the time Millar's copyright lapsed and made possible the unregulated reprinting, in England and Scotland, of editions of The Seasons as well as the production of new visual interpretations, two illustrated editions of Thomson's work in German translation had already been published.

The first complete, metrical rendering of Thomson's text into German, Barthold Heinrich Brockes's (I680-I 747) translation of I744, was an ambitious venture by the aging poet; it revealed a new interest in the descriptive impulses of poetry that would be emphasized repeatedly by editors, translators, and reviewers of German translations of The Seasons. ${ }^{7}$ In German-language communities, the poem was read, especially in the second half of the eighteenth century, in terms of reflective poetry ('eine reflectierende Poesie'), capable of combining instruction with sentiment and pathos. Johann Gottfried Herder noted: 'Schildernde Lehrgedichte sind seine [Thomson's] Jahreszeiten: denn mit Empfindung zur Lehre muss eine Gegend geschildert warden, wenn sie als Poesie in der Seele des Hörenden wirken soll'. ${ }^{8}$ This interpretive focus on the didactic character of Thomson's work is not (yet) foregrounded by the paratextual makeup of Brockes's edition, however.

The literary-historical significance of Brockes's translation lies primarily in the terms of the translator's proto-Newtonian celebration of external nature and his promotion of a physico-theological reading of the work as a religiously sublime poem. In his 1740 translation of Alexander Pope's Essay on Man, Brockes had already appended a short translation from Thomson's poem, from Spring, which he entitled 'Die wilden und unordentlichen Eigenschaften der Liebe, aus $\mathrm{Mr}$. 
Thomsons Seasons'. Equally, he translated Thomson's 'Hymn' to The Seasons in his Harmonische Himmelslust im Irdischen (I74I), verses from Summer in his Morgengedanken (I743), and lines from Spring in his Frühlingsgedicht (1743). Using the text of the 1730 quarto edition of The Seasons, Brockes also contributed translations of Thomson's Celadon and Amelia, Damon and Musidora, and Palemon and Lavinia episodes to Jacob Immanuel Pyra's collection of poems Thirsis und Damons freundschaftliche Lieder (Zurich, I 745).$^{9}$ His translations of Thomson's three signature tales reflect his identification of three of the most popular passages from the poem long before they were identified by painters and illustrators for their medial renderings of the episodes in Britain.

Also, engagement with Thomson's tales by both German and British readers culminated in the further development and sophistication of the verse tale as a genre. Readers recognized Thomson's characters, especially Celadon and Amelia, two lovers caught in a storm, who feature in the poet's moral tale of enduring love, loss, and resignation. Despite being reassured of God's protection by Celadon, Amelia fears the force and destructiveness of the storm and is ultimately struck by lightning and transformed into a petrified, 'blackened Corse' (line I2 I6), leaving Celadon behind to be 'For ever silent, and for ever sad' (line I222). ${ }^{\text {IO }}$ The one passage of the tale that British illustrators commonly captured entails the rapid succession of moments of fear, petrifaction, death, and complete stasis:

From his [Celadon's] void Embrace,

(Mysterious Heaven!) that moment, to the Ground,

A blacken'd Corse, was struck the beauteous Maid.

But who can paint the Lover, as he stood,

Pierc'd by severe Amazement, hating Life,

Speechless, and fix'd in all the Death of Woe!

So, faint Resemblance, on the Marble-Tomb,

The well-dissembled Mourner stooping stands,

For ever silent, and for ever sad. (lines I2 I4-22)

At the time when Brockes translated these tales, they were novel and soon became models for German tales in the same tragic-sentimental vein by the Swiss Johann Jakob Bodmer (who had translated sixteen verses from Spring in his Neue kritische Briefe) and Christoph Martin Wieland. ${ }^{I}$ There are even a range of translations that were published in late eighteenth-century periodicals, including 'Die Ährenleserin. Eine 
Erzählung nach dem Englischen, aus Thomsons Jahreszeiten' ${ }^{12}$ and a number of German translations of Thomson's 'Hymn' by such authors as Nikolaus Dietrich Giseke. ${ }^{13}$

Brockes's large octavo edition on fine paper was dedicated to GrandDuke Peter Foedorowitz, heir to the throne of the Russian Empire and his wife Catharina Aleriewna, and was published in Hamburg by Christian Herold late in I 744. An ornate edition, it not only included the four illustrative plate designs that Millar had commissioned from Kent, as well as a title-page printed in red and black, but also featured elaborate Rococo-style printing devices in the form of head- and tailpieces. It was prefaced by B. J. Zink in terms that underscore Brockes's interpretation of The Seasons in terms of religious poetry. The translator embeds Thomson's production within his own agenda of explaining the wonders and diversity of the creation in rational (and descriptive) terms. ${ }^{I 4}$ Zink notes:

Die mit seinem Endzweck übereinstimmende Absicht, und die glückliche Ausführung des Englischen Dichters, haben ihn dergestalt gerühret, daß er es für seine Schuldigkeit erachtet, Fleiß und Mühe anzuwenden, seinen Landsleuten die erhabene, tiefsinninge und majestätische Art, womit der Brittische Dichter seinen großen Vorwurf abhandelt, vor Augen zu legen. Die Furcht, durch diese erhabene Schreibart sich übertroffen zu sehen, hat ihn so wenig abhalten können selbige bekannt zu machen, daß er sich vielmehr verbunden erachtet, wenn er auch übertroffen wäre, den grossen Endzweck auch hierinn desto mehr befördern zu helfen, welcher bey ihm einzig und allein darinn bestehet, das wahre Vergnügen der Menschen im vernünftigen Genuß der uns von dem großen Urheber der Natur geschenkten herrlichen Gaben, nach Möglichkeit zu befördern. (unpaginated 'Vorrede') ${ }^{\mathrm{I} 5}$

Kent's mythopoeic designs offer a complex narrative that links the human with the divine spheres. (Figure I) Their large format and tonal sophistication attribute a proto-auratic power to the illustrations that is emphasized by Brockes's dedication and the fine printing of the edition as a whole. ${ }^{16}$ The plate for Summer depicts in its lower half the interpolated tale of Damon and Musidora. Damon is partially concealed behind a tree whereas the woman he loves, Musidora, is bathing. The image in Millar's I730 edition, in line with Thomson's revision of the passage, was amended for its inclusion in the I744 edition of The Seasons: Kent eliminated the other female figures and leaves Musidora sitting in the corner and establishing a direct connection with Damon by means of her gaze. The more intimate constellation of the two lovers and their textual 


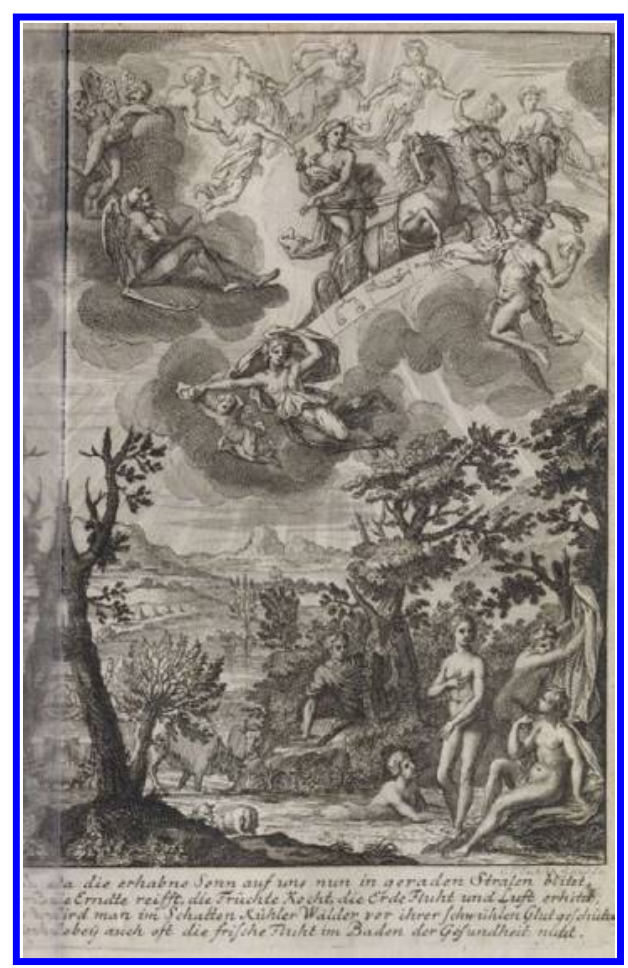

Figure I. Plate for "Sommer" (Herold's edition of The Seasons, I744, Kent's plate design [I 730 state])

transgression of propriety would determine a larger number (of especially nineteenth-century) interpretations that reject the sexualization of the tale by means of Kent's visual revision.

Unlike Millar's editions featuring these plates, Herold added explanatory, textual captions to the plates, thereby generating an even closer text-image relationship between the plate and text. Brockes's translation soon lost favour with its readers, however. By the mid-I 750 os, it was considered inadequate, not only in terms of its rendering of the original (especially in its repetitiveness and periphrastic redundancy) but also in terms of its marketability as an expensive commodity item. By I 800 , critics noted that the language of Brockes's translation could barely be understood any more. ${ }^{17}$ Also, the striking differences in format and price between Brockes's and later editions indicate that the very elite audience that Brockes had had in mind when he produced his translation had changed and that a new reading public was being targeted by more 
affordable and less ornately decorative editions of German-language translations of The Seasons.

Early negative responses to Brockes's work stimulated the production of further translations. In I757, the Swiss Zurich-based bookseller, painter, poet, and Anglophile Salomon Gessner (I730-I788)-in association with his business partner Conrad Orell - issued a translation, in duodecimo format, of the first season, Thomsons Frühling by Johannes Tobler ( $173^{2-1} 808$ ), publishing the remaining seasons in instalments in I76I and I764 respectively. The issuing of instalments was widely used in subscription editions of The Seasons (such as the I793 Perth edition released in four different numbers by Robert Morison). In Gessner's case, however, it is likely that he was testing the market, encouraging readers to collect the different instalments and have them bound together once all numbers had been published. ${ }^{I 8}$ The publisher was particularly interested in the painterly qualities of Thomson's work and Gessner's own pastoral Daphnis (I 754) closely draws on Thomson's Palemon and Lavinia tale (from Autumn). ${ }^{\mathrm{I} 9}$ Tobler was a translator, among others, of Pindar's odes and parts of the Iliad, and the author of a prose imitation of Thomson, entitled 'Die Weinlese'. He was also acquainted with Bodmer and may have known of the latter's early translations of Thomson's work. In his translation, Tobler succeeded in offering a more lucid style than his predecessor, although there are frequent instances of his language being inflected by provincialisms.

Not only did Gessner's edition provide a more accurate, reliable, and affordable version of Thomson's work, using the 1744 rather than the I 730 variant of Thomson's poem (which Brockes had used), but it also deployed a more compact publishing format that later booksellers would frequently adopt when marketing a British classic. In the preface, the translator notes his indebtedness to Brockes, but insists at the same time that Brockes's translation significantly obscured the beauties of the poem: 'Bisher haben wir dieses Gedicht in der Übersetzung nur in einem Nebel gesehen, in welchem die kleinern Schönheiten verschwanden, und die grössern ihre Farbe und Anmut verlohren'. ${ }^{20}$ A reviewer considered Brockes's translation 'elend' (miserable) but commended Tobler's rendition as a more faithful effort to translate the character of Thomson's production. Tobler identifies as the reason for the failure of Brockes's project the poet's insistence to impose upon Thomson's blank verse the 'yoke of rhyme' ('das Joch des Reimes'). In their small, duodecimo format, Gessner's volumes distinguished themselves strikingly from the earlier, expensively produced edition 
featuring Kent's full-page copper-engraved tableau designs. Gessner's edition included one small, emblematic vignette on the title-page of each of the instalments of the translated seasons. Gessner's vignettes are sentimentalizing and atmospheric and, as in the case of the title-image for Winter, do not engage with the text in any specific way. The one exception is the design for the title-page of Summer which introduces a bathing scene in which putto-versions of Musidora and Damon are placed into an environment that was originally defined in terms of desire and the erotic, as the large number of book illustrations in British editions as well as Angellica Kauffman's design for a furniture engraving confirm. (Figures 2 and 3 ) The bathing Musidora, being spied on by Damon, had been depicted less centrally in Kent's design. Gessner's re-inscribing of this scene with an ideology of innocence that reduces Thomson's complex interpolated tale to an encounter of two children-wherein the female is not clearly differentiated from the male-represents a rewriting that was often found necessary by critics objecting to the moral ambivalence of Thomson's narrative. ${ }^{21}$ More generally, the use of putto figures facilitated Gessner's generating a uniform design feature for some of his German-language editions of popular English texts, including his edition of Collins's Oriental Eclogues, thereby anticipating a medium of seriality that, in Britain, emerged only in the I 780 s and I 790 os.

Tobler's improvement on Brockes's translation and especially his version of the Celadon and Amelia episode are striking. A brief comparison of the passage narrating Amelia's death and Celadon's response demonstrates in which ways Tobler had gone beyond Brockes.

Aus seinen Armen fiel, o des geheimen Schicksals!

Das schöne Kind denselben Augenblick

In einen Aschenhaufen. Aber wer,

Wer kan izt den Liebhaber recht abschildern,

Wie er erstaunt, wie ganz erschlagen, stuhnd?

Er stuhnd ganz sprachlos da, das Leben hassend,

Und fühlte tausendmahl in tausend Schmerzen

Den Tod, doch dieses Gleichnis ist nur matt,

Der Traurende auf eines Grabmals Marmor

Gebückt, auf ewig stumm, auf ewig jammernd. ${ }^{22}$

Aus seiner leeren Umarmung

Ward (o geheimnisvoller Himmel!) das huldreiche Mädgen

Augenblicklich, ein schwarzer Leichnam, zu Boden geschlagen.

Aber wer kann den Liebenden schildern, so wie er gestanden,

Von dem ernsten Erstaunen durchbohrt, dem Leben gehässig, 


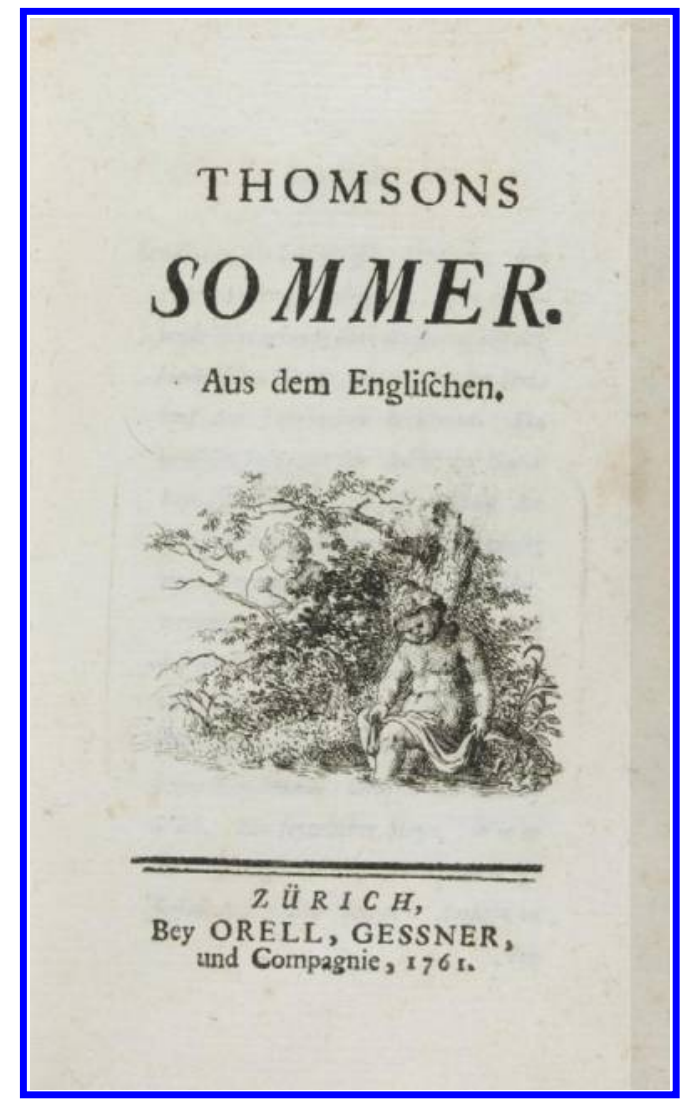

Figure 2. Title-page of Gessner's edition

Sprachlos, und festgeheftet in jedem Tode des Schmerzens! Allso (schwache Vergleichung!) steht auf dem Marmor des Grabes, Der wohlnachgeahmte Traurende, niedergebeuget;

Immer schweiget er still, beständig in gleicher Betrübnis. ${ }^{23}$

Apart from the general difference that Brockes and Tobler used different variants of Thomson's extensively revised poem, Brockes's periphrasis of Amelia's 'blacken'd Corse' in terms of a heap of ashes denotes the lover's absolute destruction but does not encompass the monumentalizing of the lover so prominently visualized in a large number of British illustrations. Amelia's infantilizing contrasts with the deliberate gendering that all later translators emphasize; it is her attractive femininity and erotic potential - even in death - that designers 


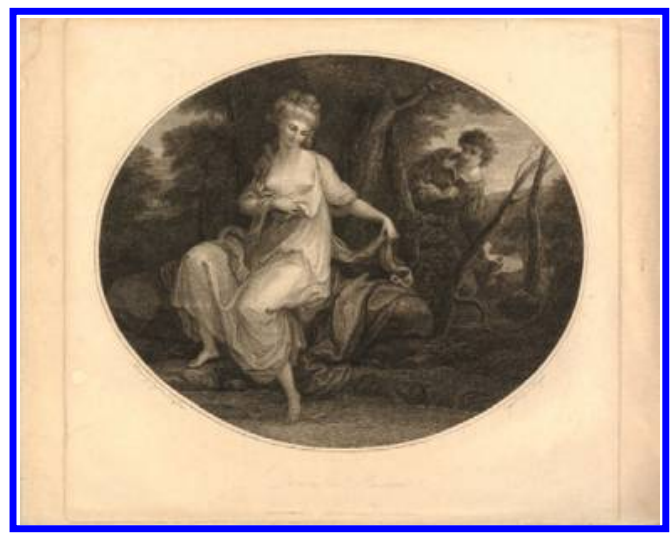

Figure 3. Furniture print by Angellica Kauffman, representing Damon and Musidora ( $178 \mathrm{I})$

frequently represented. Equally, Brockes renders Celadon's embrace of Amelia too generally without indicating that the embrace has become 'void' and meaningless because the lover, who had protectively been encased by Celadon's arms, is no longer able to reciprocate his physical proximity and love.

One year after the publication of the first instalment of Tobler's translation, a new, complete translation in quarto by Johann Franz von Palthen (1724-1804) was issued in Rostock; it was reprinted in a second edition in Rostock in 1766 and, in a third, in Berlin in $178 \mathrm{I}$. While von Palthen's work has fared equally badly in the critical reception of German translations of Thomson's poem as Brockes's, ${ }^{24}$ his edition was remarkable for its set of four new plates and a large number of elaborate printing ornaments. ${ }^{25}$ The title-page features a plate $(5 \mathrm{~cm} \times$ $8.7 \mathrm{~cm}$ ) depicting the four allegorized Seasons on clouds. Each allegory is represented by two cherubs with seasonal attributes, and these groups surround a globe. While the two cherubs of spring are holding garlands and are strewing flowers onto the earth, one of the figures of summer is holding a plate full of grapes. Autumn is represented by one cherub with a sheaf of corn, the other with a sickle, whilst the cherubs representing winter shower snow onto the earth and blow the winds of coldness and death to which the perishing man in Winter succumbs. The title-page contracts individual seasonal narratives that in Kent's designs had been developed in complex and elaborate ways. 
Richly illustrated, using rococo head- and tail-pieces, the edition distinguishes itself from Herold's through its profusion of printing devices. The first page of 'Leben des Herrn Jacob Thomson' (derived from Lessing's I 756 account for his edition of Des Herrn Fakob Thomson sämtliche Trauerspiele) is an impressive example of engraving design and contains a large baroque-style headpiece. Von Palthen's is the first German edition of The Seasons that prints a biography of Thomson and his account for the revised I 766 edition is modelled very closely on the one that Patrick Murdoch, a friend of Thomson's, had contributed to Millar's I 746 royal quarto (subscription) edition of The Seasons. The layout of Von Palthen's translation of Murdoch's biography is more complex than Millar's had been: an engraved cornucopia precedes the first sentence of the text. The text of this page is set out ambitiously, and the various ornaments underscore the otherwise expensive execution of this edition in small quarto. Its designer was Gottlieb Leberecht Crusius (I730-I804) who took inspiration from Kent in that he illustrated the divine sphere with a group of seasonal deities, both male and female. Crusius was a talented engraver who designed original illustrations for works ranging from belles lettres to the natural sciences but who also used the work of Hubert-François Gravelot as inspiration. He was the brother of Carl Leberecht, also an engraver, and Siegfried Leberecht Crusius ( I $^{8}{ }^{8-1}$ 824), a successful bookseller working in Leipzig.

In terms of illustration, this edition is more complex than Millar's and Herold's editions featuring Kent's designs. It includes significantly more ambitious head and tail-pieces, an indication that this edition was launched as a major intervention in the German appropriation of The Seasons as a cultural classic of transnational importance, as well as an impressive competitor of the other two German-language editions of Thomson's work. The designs adopt some of the iconographic features of Kent's designs. Male figures are depicted with butterfly-like wings, while the principal female figure dispenses flowers to a cherub. Another group of cherubs bind garlands from flowers. The seasonal design for Frühling, even more so than Kent's, is in baroque style; it also represents the Kentian rainbow but introduces a decidedly different rendering of the human sphere: three figures are in the foreground, one (on the left) wearing a large periwig, the other two (on the right) dressed in expensive garments and apparently going for a walk. The path on which they walk leads past groups of cattle, a horse, and a farmer ploughing a field, to a villa with a gate. The execution of the engraving, especially of the detail in the depiction of the distant landscape, is excellent. In detail, Crusius 
outdoes Kent, particularly in the design of trees. In its introduction of clearly recognizable fashions and architectural feats, the plate assembles elements and iconographic moments not represented in British editions, as well as an 'updating' of Kent's more classical visual compositions.

The mythological group of deities featuring in the plate for Summer, with the deity's car drawn by coursers, and winged cherubs sleeping on the right, is also more elaborate than Kent's design for the same season. Following Kent, Crusius introduces Musidora and Damon but separates them-by means of divine intercession-from a group of hunters who have just killed a wild boar. A deity with a cloak, probably a symbolic representation of the guardian of chastity, has thrown a veil of impenetrable smoke over the scene of intimacy enacted in Damon's spying on the bathing Musidora, thereby avoiding the erotic contexts that Gessner had rewritten in his vignette of two putto figures. The plate for Autumn depicts a scene of harvest in the lower half, and a figure gathering grapes from the vines on the left. While doing so, he directs his gaze upwards to observe the deities of the season. The seasonal attributes are dispensed by a cornucopia, and the presiding deity is feeding some grapes to a dog. In the lower right hand corner of the plate, there is a basket overflowing with ripe fruit. The Winter plate privileges the divine sphere in that the divinities are able to establish full sway over the human landscape. The deities dispense ice and snow, and the human life of the scene (represented in much smaller scale) is rendered in terms of seasonal activities such as the riding of sledges. A major building structure is shown in the background, and a frozen font occupies the right section of the plate, opposite a wild (but nevertheless amiable-looking) bear, an animal which does not ever feature in the illustrations of British editions of The Seasons.

Even though Tobler was usually commended at the expense of Brockes and Von Palthen, Christian Heinrich Schmid (I 746-I80o), the important translator and popularizer of British poetry, in 1769 , captured the general dissatisfaction with the standards of existing translations of The Seasons:

Ins Deutsche ist Thomson noch nicht völlig so übersetzt, als er es verdiente. Brockes Übersetzung ist vergessen, und Palthen hat sich durch die seinige einen vorzüglichen Rang unter den schlechten Übersetzern erworben. Der schweitzerische Übersetzer hat sein Original nicht zu erschöpfen geglaubt, wenn er nicht ängstlich alle Rauhigkeiten und fremde Zusammensetzungen desselben übertruge, den schweitzerischen Dialekt ungerechnet. Es ist, als wenn man uns in einen vortrefflichen Garten führte, und die Gänge mit lauter Steinen bestreut hätte, 
über die wir alle Augenblicke stolpern müssten. Thomson sollte uns vergnügen, und hier macht er uns bange. ${ }^{26}$

Schmid's call for a translation that encompasses the descriptive spirit of The Seasons was answered by Ludwig Schubart ( $1765^{-1} 8$ I I ) who in his edition of $\mathrm{I} 789-$ Jakob Thomson's Jahreszeiten. Neu übersetzt.... mit fünf Kupfern-not only offered the best translation to date but also included an extensive rationale of his translating task. ${ }^{27} \mathrm{He}$ recalls:

Bey der ersten Durchlesung der Thomsonschen Jahreszeiten hatten mich einige Episoden so gereizt, dass ich der Lokkung nicht widerstehen konnte, einen Versuch zu machen, ob sich diese bezaubernde Wirkung nicht auch in einer Deutschen Nachbildung vorbringen liesse. Ich wagte mich an diese Nachbildung, machte einige Proben davon bekannt; - und der nachsichtsvolle Beifall, womit diese aufgenommen wurden, bestimmte mich, nach und nach alle vier Jahreszeiten in der nehmlichen Manier zu bearbeiten. ${ }^{28}$

This first attempt may well be the anonymously published pamphlet, Bey Übersendung einer Übersetzung aus Thomsons Jahrszeiten, im April I783. Schubart singles out Tobler's translation as the one that is most literal, but generally unpoetic, rough, and tiring ('unpoetisch, rauh und ermüdend'), noting that Tobler's insistence on literality has occasionally led him to commit errors. He explains that he has had to take some liberties in appropriating the text ('gewisse Freiheiten in Ansehung des Textes'), as Thomson continuously deploys highly hypotactical constructions, including numerous parentheses, as well as such a large number of epithets the literal translation of which would have resulted in a tiring effect on the reader. ${ }^{29}$ As a result, he has disentangled some of the textual complexity of The Seasons, simplified and shortened the syntax, repositioned or omitted some of the epithets, and sought to capture the sound and smoothness of the original blank verse by translating it as metrical prose.$^{30} \mathrm{~A}$ reviewer of Schubart's translation commended the translator's talent and poetic feeling, the inclusion of the preface and his rationale for translating the poem, as well as his ability to encompass complex pictorial and descriptive structures. ${ }^{31}$ Morton Stewart, similarly, notes the significant improvement on earlier translations that Schubart's work represented:

We no longer have to deal with a crude, unpoetic, tiresome rendering, laughable on account of literalness, and displeasing in its dialect. Here we find an attempt not only to interpret to the reader Thomson's thought, but also to awaken in him something of the charm and beauty which the original possesses. It is a good, smooth prose work, quite free from foreign words and idioms, and no phrases or constructions which are dialectic or un-German. ${ }^{32}$ 


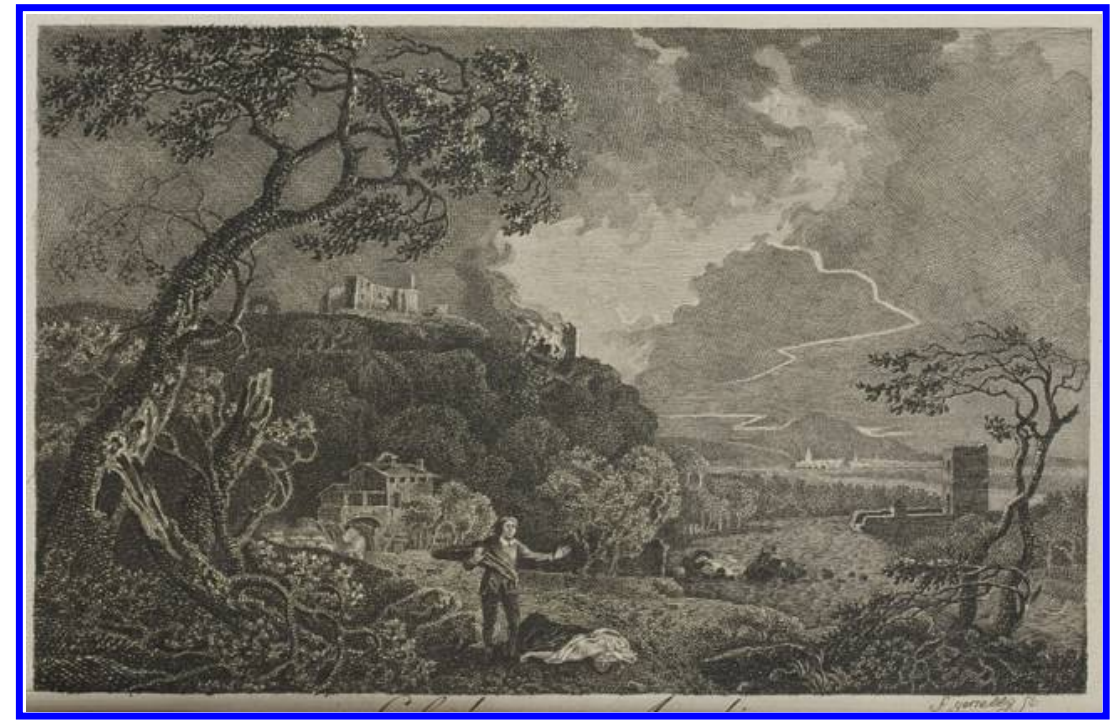

Figure 4. Folding-plate depicting Celadon and Amelia (I789)

Schubart's translation enjoyed significant popularity and was issued in three different editions. ${ }^{33}$ These editions contained five copper-engraved full-page plates, after George Smith, Richard Wilson, and Thomas Jones, and were engraved by Friedrich Genelly. One of these plates is a scaleddown and technically simplified version of Woollett's furniture print of Celadon and Amelia, an elite graphic rendering and the first English visual interpretation of the tale after the lapse of Millar's copyright. (Figure 4)

The edition also included a second design by Wilson, entitled 'Solitude', which had been published as a furniture print in Britain in $177^{8.34}$ With the exception of the Celadon and Amelia plate, the engravings had not previously been used to illustrate the poem. Yet, in their representation of select iconographic moments such as the gathering of nuts and the rendering of landscape scenes they anticipated the wide range of interpretative prints published in Britain in the I79os. Significantly, the two plate designs after Wilson were not used for book illustrations of The Seasons in Britain. Rather, they were based on large-scale, folio furniture engravings, meant for collecting, framing, and display in the home as status symbols. They were commodities for elite consumption. Overall, the plates in Schubart's editions underscore the mid-eighteenth-century approach, including Kent's, to reading The 
Seasons as a holistic, if anthological, rendering of the various creative acts of God in nature; the landscape frequently functions as a theatre of the forces of Thomson's theodicy. ${ }^{35}$ Apart from the significantly smaller and simplified designs of Woollett's tonally sophisticatedly executed furniture engravings, the edition also comprised a more recent frontispiece, as well as a likeness, in oval format, of Thomson. Schubart's publisher recycled the emblematic-allegorical title-vignette that Thomas Stothard ( $\left.1755^{-1} 834\right)$, one of the most important late eighteenth-century book illustrators, had designed in the early $\mathrm{I} 78 \mathrm{os}$ and which would, eventually, feature on the engraved title-page of Archibald Hamilton's I 793 London quarto edition. Stothard illustrated Thomson's text on four occasions, producing four different sets of designs for editions of The Seasons. The publisher's choice of Wilson's early visualizations of scenes from the poem and the later Stothard vignette indicates an attempt to combine earlier paratextual interpretations, to engage with the critical tradition and the reception of The Seasons (as Schubart had tentatively done in his preface), and to align his edition with the complex archive of visual interpretations that designers and painters had produced from I 730 onwards.

The recycling of earlier editorial material and illustrations also informed another edition of The Seasons, edited by J. J. C. Timaeus, that was initially published in Hamburg in $\mathrm{I} 790$ and reprinted at Leipzig in I 794. Timaeus's octavo volume was an English-language edition and reused and slightly modified a frontispiece depicting the four seasons that had been published 'By the booksellers' in London in I795. (Figure 5) It also reprinted John Aikin's 'Essay on the Plan and Character' of Thomson's poem. Two earlier, unillustrated and less ambitious Englishlanguage editions had been published in $\mathrm{i} 766$ (apparently a collaborative project between the London bookseller James Dodsley and the Leipzig bookseller C. Moser) and I78 I (for the Leipzig-based bookseller E. B. Schwickert). Both Moser's and Schwickert's editions were meant for use in schools, each carrying line numbers; and Moser's was issued and sold in glossy green wrappers..$^{36}$

Bernhard Fabian has explored the presence and significance of British texts in Germany and argued that while 'English was... the foreign language of a cultured minority', it nevertheless provided a cultural model that German readers sought to emulate. According to Fabian, 'an elite group of occasional translators', rather than the professional late eighteenth-century translator, contributed to the popularization of novel trends in literary discourse and practice. ${ }^{37}$ Similarly, some of the 


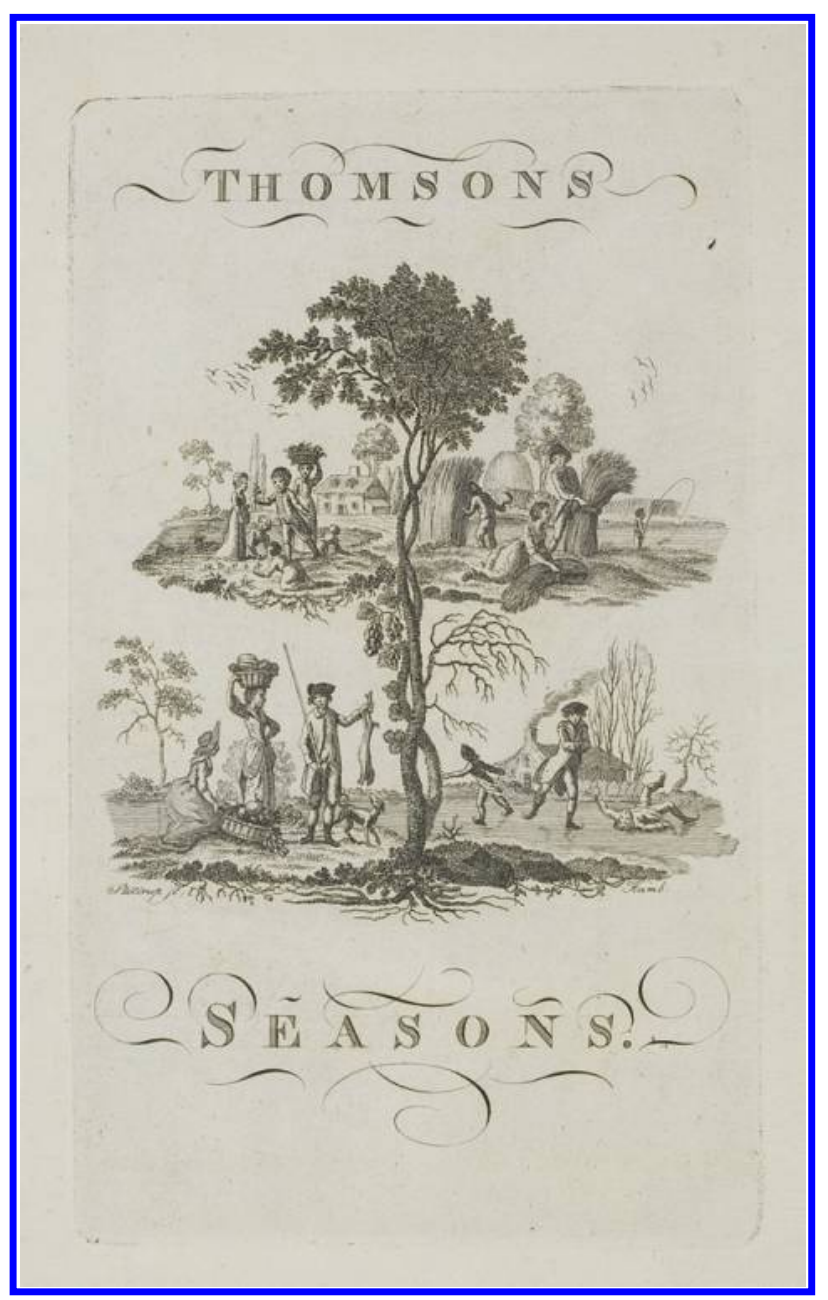

Figure 5. Frontispiece to Timaeus edition

illustrated editions stimulated critical engagement with the iconographic traditions and models used in the course of the century and enabled innovative interpretations that, especially because of the dominant influence of French culture and books, often culminated in unique negotiations of visual paratexts.

The preface in Schwickert's edition explicitly states that the volume is 'chiefly intended for the use of schools, correctness and cheapness have been more consulted than that elegance and splendour, which too often exceeds the narrow circumstances of the diligent, but indigent 
youth'. ${ }^{3}$ Timaeus's edition, by contrast, printed on good paper and carrying a complex frontispiece, as well as including an introduction, presented itself as an elegant edition to its readers. As editor, Timaeus aims to associate himself closely with English editions and editorial practice, especially in terms of the paratextual material such as his preface in which he hails The Seasons as 'the original whence our modern descriptive poets have derived that more elegant and correct style of painting natural objects which distinguishes them from their immediate predecessors' ${ }^{39}$ He follows in the tradition of readers like the mideighteenth-century critic Joseph Warton who understood the poem as the product of verbal painting: 'Each [season], too, like the prismatic colours, is indistinguishably blended in its origin and termination with that which precedes, and which follows it; and it may be expected from the pencil of an artist to hit off these mingled shades so as to produce a pleasing and picturesque effect. ${ }^{\prime \circ}$ His edition of the text, following Millar's and most later British editions, reprinted William Collins's ode on the death of Thomson. In its engagement with the critical tradition of Thomson's work, the edition catered for those late eighteenth-century readers who sought to read the poem in the original, rather than in translated form. ${ }^{4}$

The last eighteenth-century illustrated edition of a German translation of Thomson's classic was published by I. F. Hammerich in Altona in 1796 . It was prepared by Heinrich Harries ( $1762-1802$ ), a clergyman working in Bruegge, near the north-German city of Kiel. A second edition was issued in Vienna in I802. Not only was this edition introduced by an ambitious illustrative frontispiece which is tonally far superior to the one accompanying Timaeus's edition, but it also included Harries's detailed prefatory essay in which he explains his choice of the iambic metre. Like Schubart, Harries was intent on capturing the 'music of the verse', the poem's style, but also the genius ('Genius') of the German language..$^{42} \mathrm{He}$ also notes that he sought to avoid the continuous use of the enjambement so typical of Thomson's work, while at the same time creating small, integral units of verse, which Harries sees as contributing to a 'gerundetem Ganzen' (a rounded whole). Acknowledging Lessing, Goethe, and Schiller as his models, he added a feminine syllable to the fifth iambic foot, thereby creating variety. ${ }^{43}$

Hammerich's edition marked a clear break with the illustration practice that had characterized all German and British editions. (Figure 6) His emblematic frontispiece connects the metaphor of the serpent-standing for the cycle of the seasons and time - with attributes related to the different seasons. It neither features man, nor are those 


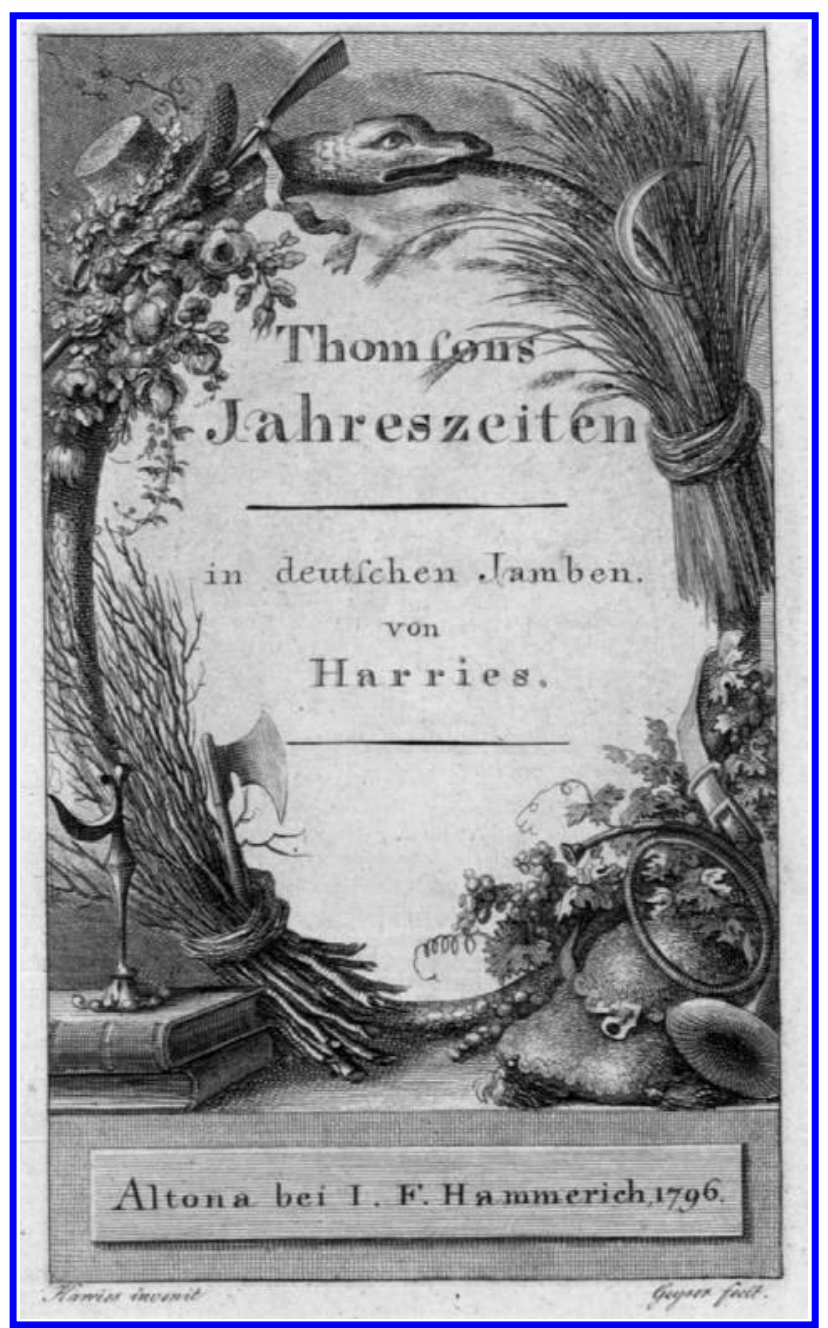

Figure 6. Engraved title-page of Harries's edition

divinities introduced that were integral to most eighteenth-century visual interpretations of The Seasons. The designer constructed a dynamic oval form that encases the title of the poem and serves as the dynamic backdrop, insisting, as Schubart's publisher had already done, on a close text-image relationship that made the text present in ways that differed significantly from the mythologizing visual narratives of Kent's allegorical canvas designs. 
As in Britain, German commentators, including I. Horn, singled out Thomson's interpolated episodes for particular praise: 'Welche Wahrheit, welche Feinheit, welche unbeschreibliche Grazie und Wohlklang herrscht darin! Verschiedene Freunde von Thomson haben ihm gerathen, mehrere dergleichen Erzählungen in seine Iahrszeiten einzuweben, um das Interesse dadurch aufzufrischen, und mehr Leben und Handlung in seine Gemälde zu bringen'. ${ }^{44}$ The tales were occasionally excerpted and translated for inclusion in anthologies and offered an iconographic repertoire that stimulated artistic responses, in Britain, up until the mid-I86os. Strikingly, despite the popularity of the Celadon and Amelia episode (and its different translations) in the eighteenth-century German-speaking world, the tale was not illustrated beyond Schubart's edition. The combinatory format introduced by Schubart's edition, re-using different but hitherto unconnected visualizations of Thomson-related material, provided an interpretive move away from the high-cultural interpretation promoted by the translations of Brockes and Von Palthen. Gessner's title-vignette for Summer demonstrated his ability to domesticate the erotic matrix of the Damon and Musidora episode. His rewriting of Thomsonian textuality marks an important step in the paratextual appropriation of The Seasons. It inaugurated the search for ways in which Thomson could be comprehended not only in the German language; rather, it made possible an exploration of the possibilities that print culture and the medium of the engraved plate offered booksellers in their attempts to appropriate Thomson's work and offer engraved visual paratexts that promoted specific interpretations. The move, from the late $\mathrm{I} 78 \mathrm{os}$, to focus on images of landscape, the natural cycle, and emblematic composite frontispieces of The Seasons anticipated some of the impulses of natural description that predominated the poem's visual life in nineteenth-century Britain. The visual fashioning of The Seasons in editions of German-language translations, especially the illustrative engagement with the interpolated episodes, was an important part of the continental reception of Thomson and contributed significantly to reading this cultural classic in terms that had not been used in its British visual interpretations.

The research for this article was made possible by two funded library fellowships at the Herzog August Bibliothek Wolfenbüttel (HAB) and the Klassik Stiftung, Weimar. 


\section{NOTES}

I See J. H. Heinzelmann, 'Pope in Germany in the Eighteenth Century', Modern Philology, Iо:3 (I913), 317-64. Bernhard Fabian and Marie-Luise Spieckermann, 'Alexander Pope in Eighteenth-Century Germany: A Bibliographical Essay', Smift Studies I5 (2000), 5-32; I6 (2001), 5-32, I7 (2002), 5-35.

2 James McLaverty's magisterial Pope, Print and Meaning (Oxford: Oxford University Press, 200I) has offered the most complete account to date of the poet's uses of the complex resources of the book trade as well as the ways in which visualizations of his works promoted particular reading patterns.

3 Knut Gjerset, Der Einfluss Fames Thomsons Fahreszeiten auf die deutsche Literatur des I8. Fahrhunderts (Heidelberg: Buchdruckerei von K. Geisendörfer, I 898). See also, C. H. Ibershoff, 'A German Translation of Passages in Thomson's Seasons', Modern Language Notes 26:4 (I9I I), I07-I09; Ibershoff, 'Bodmer and Thomson's Seasons', Modern Language Notes 4I: I (I926), 29-32; John A. Walz, 'Schiller's Spaziergang and Thomson's Seasons', Modern Language Notes 2 I:4 (I906), I I 7-I 20, and Marie-Luise Spieckermann, 'The Seasons transformed into Die Jahreszeiten: James Thomson's Poem and Gottfried van Swieten's Libretto', The Perennial Satirist: Essays in Honour of Bernfried Nugel, edited by Peter E. Firchow and Hermann J. Real (Munster: LIT, 2005), pp. 83-103.

4 See Rudolf Sühnel, 'James Thomsons The Seasons mit William Kents Illustrationen', Die Vier Fahreszeiten im I8. Fahrhundert (Heidelberg: Carl Winter, I986), pp. I8-29. For a broader discussion of illustrations of Thomson's poem in the eighteenth century, see Sandro Jung, 'Print Culture, High-Cultural Consumption, and Thomson's The Seasons, I780-I797', Eighteenth-Century Studies 44:4 (201 I), 495-5I4.

5 See Sandro Jung, 'Visual Interpretations, Print, and Illustrations of Thomson's The Seasons, I730-1797', Eighteenth-Century Life 34:2 (2010), 23-64. Kent's plates replaced a set of four allegorical designs, based on marble statues in the gardens of Versailles, that accompanied another I 730 edition of The Seasons. These plates do not occur beyond 1738 and Kent's designs are then the only visual interpretations of The Seasons, in book publications, until I 770.

6 See Sandro Jung, 'Painterly "Readings" of The Seasons, 1760-1829', Word E Image 26: I (2010), 68-82.

7 See Morton Collins Stewart, 'Barthold Heinrich Brockes' Rendering of Thomson's Seasons and the Later German Translations. Part I. The Translation of the Seasons by B. H. Brockes', The Fournal of English and Germanic Philology Io: I (I9II), 20-4I; Stewart, 'Barthold Heinrich Brockes' Rendering of Thomson's Seasons and the Later German Translation', The Fournal of English and Germanic Philology, I0:2 (I9I I), I97-2 I3, and Stewart, 'Barthold Heinrich Brockes' Rendering of Thomson's Seasons (Continued)', The Fournal of English and Germanic Philology, го:3 (г9г I), 378-4I4.

8 Johann Gottfried Herder, Briefe zur Beförderung der Humanität (Riga: bei Johann Friedrich Hartknoch, I796), p. 97, p. 96: 'Thomson's Seasons are shining didactic poems: for, in order to work on the soul of the listener as poetry, a landscape has to be depicted with susceptibility to instruction'. All translations from the German are mine. 


\section{Print Culture and Visual Interpretation}

9 C. H. Ibershoff, 'A German Translation of Passages in Thomson's The Seasons', Modern Language Notes 26:4 (I9I I), I07-I 09 .

Io James Thomson, The Seasons, ed. by James Sambrook (Oxford: Clarendon Press, I98I), p. I I6. All further quotations are from this edition and line references will be given in parentheses.

I I See C. H. Ibershoff, 'Bodmer and Thomson's Seasons', Modern Language Notes 4r:I (I926), 29-32. On the genre of the verse tale, see August Fresenius, 'Die Verserzählung des I8. Jahrhunderts', Euphorion 28 (I927), 5 I9-40, and Sandro Jung, 'Thomson's The Seasons and the Tragic-Sentimental Verse Tale', Forum for Modern Language Studies 47:I (201 I), 3-I 5. Also, more generally, Lawrence Marsden Price, English Literature in Germany (Berkeley and Los Angeles: University of California Press, I953), p. 82.

I2 HAB shelfmark: M: Lq I277 (I4).

I3 Price, English Literature in Germany, p. 80.

I4 'Schon seit langen Jahren hat er [the translator] sich eine Pflicht und ein Vergnügen daraus gemacht, die Menschen unter den Geschöpfen herum zu führen, und ihnen die Weisheit und Schönheit in der Übereinstimmung der mannigfaltigen Werke der Natur zu zeigen und zu lehren' (Zink, unpaginated preface).

I5 'The English poet's intention and his corresponding final purpose, as well as his happy execution, have moved him to such a degree that he regarded it his duty to lay before the eyes of his fellow citizens the sublime, profound, and majestic art with which the British poet depicted his grand design. The fear to be overreached by this sublime way of writing has not deterred him from making the same public. For, in this task, irrespective of whether he be outdone, he feels bound to promote the true pleasure of man in the rational enjoyment of the gifts bestowed by the great originator of nature.'

I6 See Walter Benjamin, Das Kunstmerk im Zeitalter seiner technischen Reproduzierbarkeit, ed. by Burkhardt Lindner (Stuttgart: Reclam, I989), pp. I9-20.

I7 I.Thomsons Iahrszeiten, mit kritischen, ästhetischen und erklärenden Anmerkungen von I. P. und I. Horn (Halle: in Verlag bei Ioh. Christian Hendel, I8oo), p. lxvi.

I8 From copies that I have examined in the Beinecke Rare Book and Manuscript Library, Yale University, editions of Thomsons Gedichte (1764) do not merely bind remainder copies of the individually issued instalments. See copies at the following shelfmarks: Zg ${ }_{1} 8 \mathrm{~T}_{553} 7_{764 \mathrm{t}}$ (Gedichte) and BEIN Ik $\mathrm{T}_{3} 84$ En757 (individual instalments). Individual instalments have retained their original title-pages.

I9 Price, English Literature in Germany, p. 83. He also continued to publish fashionable English works such as Collins's Orientalische Eklogen (I777), and the prefaces to his translations of English works frequently attempt to embed these productions within a programme of cultural patriotism that poets in the German-speaking world were keen to cultivate. See Sandro Jung, 'Salomon Gessner and Collins's Oriental Eclogues', Neophilologus 93:3 (2009), 369-376.

20 Thomsons Frühling (Zurich: bey Gessner, I757), p. 3: 'Hitherto we have seen this poem in its translation only as through mist, in which the smaller beauties disappeared and the greater ones lost their colour and grace.'

2I On the ways in which readers and designers tried to resolve the moral and erotic ambivalence of the Damon and Musidora episode, see Ralph Cohen, The Art of 
Discrimination: Thomson's 'The Seasons' and the Language of Criticism (London: Routledge \& Kegan Paul, I964), pp. 29I-300.

22 Jacob Immanuel Pyra, ed., Thirsis und Damons freundschaftliche Lieder (Zurich, n. pub., I745), p. 88.

23 Johannes Tobler, translator, Die Fahrzeiten des Facob Thomson. English-Deutsch (Basel: bey Johannes Schweighauser, I768), p. I 59.

24 Stewart, The Fournal of English and Germanic Philology, Iо:3 (I9I I), 390-394.

25 Jacob Thomsons Fahrzeiten [sic] aus dem Englischen nach der neuesten Ausgabe übersetzt von Fohann Franz von Palthen. Mit Kupfern (Rostock: im Verlag der Koppischen Buchhandlung, I758).

26 Christian Heinrich Schmid, Biographie der Dichter, 2 vols. (Leipzig: in der Dyckischen Buchhandlung, I769), vol. I, p. 533: 'Thomson has not altogether been translated as he deserves. Brockes's translation is forgotten, and Palthen has acquired a high rank among the bad translators. The Swiss translator has not thought it possible to exhaust his original when he timidly transposed all roughness and strange compounds, not to mention his Swiss dialect. His translation resembles a beautiful garden the paths of which are strewed with stones that cause the reader to stumble at every moment. Thomson should delight us, but here he makes us anxious.'

27 (Berlin: Himburg, I 786 ).

28 Schubart, p. xxxiv: 'On first reading Thomson's Seasons, I was moved by some of the episodes to the degree that I could not resist the temptation of making an effort and recreating its charming effect in a German translation. I ventured on this translation, made some excerpts public, and-owing to the generous applause with which my version was received-decided to translate one by one all four seasons in the same manner.'

29 Schubart, p. xxxvii, p. xxxiv. He notes: 'Thomson hat ... fast durchgehend so viele Zwischensätze, so lange und tiefverschlungene Perioden, und eine solche Menge an Epitheten, das seine ganz treu Übertragung im Deutschen Widerwillen und Erschlaffung erregen müsste' (p. xxxv).

30 Schubart, p. xxxvi.

3I Allgemeine deutsche Bibliothek, 96 (I790), 404.

32 Stewart, p. 394.

33 Jakob Thomson's Jahreszeiten. Neu übersetzt. Mit fünf Kupfern (Berlin: Christian Friedrich Himburg, I789).

34 These two plates illustrate Summer.

35 See Schubart's statement: 'Diese Gemälde weiss unser Dichter überall durch grosse ihm eigene Ideen über Gott, die Natur, den Werth, und die Bestimmung des Menschen, über Sittlichkeit, Welt und Menschengeschichte so aufzufrischen, und fester an sein Herz zu knüpfen' (pp. xvi-xvii).

36 The copy at the HAB still has these original wrappers.

37 Bernhard Fabian, The English Book on Eighteenth-Century Germany (London: The British Library, I992), pp. 77-78; p. 8o.

38 James Thomson, The Seasons. A New Edition, to which is prefixed an essay on the plan and character of the poem (Leipzig: Schwickert, I78I), p. i.

39 The Seasons. By James Thomson. A Nem Edition, Revised and Corrected by 7. 7. C. Timaeus (Hamburg: printed for J. H. and J. G. Herold by G. F. Schniebes, I79I), p. xxviii. 


\section{Print Culture and Visual Interpretation}

40 Timaeus, p. xxxi.

4I Collins's ode was frequently reprinted in a range of British editions in the second half of the century. Christian Heinrich Schmid translated the ode for inclusion in the first volume of Biographie der Dichter ( I 769).

42 Heinrich Harries, translator, Thomsons fahreszeiten in deutschen famben (Altona: I. F. Hammerich, I796), pp. lxvii-lxviii.

43 Harries, p. lxix, p. lxx.

44 I.Thomsons Iahrszeiten, mit kritischen, ästhetischen und erklärenden Anmerkungen von I. P. und I. Horn (Hendel, I8oo), p. I62. 